\title{
Contributions of Walter G. Ridewood to systematic comparative anatomy, especially of the osteology of "lower" vertebrates
}

\author{
ERIC J. HILTON ${ }^{1} \&$ PETER L. FOREY ${ }^{2}$ \\ ${ }^{1}$ Geology Department, Field Museum of Natural History, Chicago, IL, USA, and ${ }^{2}$ Department of \\ Palaeontology, The Natural History Museum, London, UK
}

(Accepted 1 fuly 2004)

\begin{abstract}
Walter George Ridewood (1867-1921), an English comparative anatomist, was influential for many reasons, including his methods for preparing anatomical specimens and the factual results of his studies, as well as through his approach toward systematic comparative anatomy. Ridewood was not limited to expertise in any particular taxonomic group, but rather researched and published on many groups and anatomical systems, most notably on the hyoid apparatus of basal anurans, the skull of basal teleostean fishes, the gill morphology of lamellibranch molluscs, and the morphology and taxonomy of the pterobranch Cephalodiscus. In this paper, we describe Ridewood's life, and discuss his influence, particularly in regards to the systematic osteology of teleostean fishes. We provide a partially annotated list of Ridewood's published works.
\end{abstract}

Keywords: Comparative anatomy, osteology, Pipidae, Pterobranchia, Teleostei

\section{Introduction}

The research of Walter G. Ridewood, a comparative anatomist working in London at the turn of the 20th century, influenced future generations of researchers through his methods for preparing anatomical specimens, the factual results of his studies, as well as through his approach toward systematic comparative anatomy. Ridewood's approach can be seen, in some ways, to foreshadow the modern basis of phylogenetic systematics. Colin Patterson (short biographical notes for persons mentioned are included as Appendix 2) is said to have considered Ridewood one of the most influential ichthyologists of his time (L. Grande, personal communication, 2001). Ridewood was indeed influential, although he was also overshadowed by the reputations of his colleagues working in London at that time, many of whom enjoy great places in the history of ichthyology (e.g. A. C. L. G. Günther, G. A. Boulenger and C. T. Regan) and palaeontology (e.g. A. S. Woodward). Of his publications, the five papers that Ridewood published regarding the teleostean skull (1904a, 1904b, 
1904c, 1905a, 1905b) have had the greatest impact on our own research on the osteology and phylogeny of basal teleostean fishes (e.g. Greenwood 1970; Forey 1973; Patterson 1975; Forey et al. 1996; Hilton 2001, 2002, 2003; Bemis et al. 2004). It is 100 years since the publication of Ridewood's first paper on the skull of a basal teleostean fish-the inspiration offered to us-and on account of this it seems appropriate to celebrate the impact of his work on modern comparative ichthyology and herpetology.

In this paper, we will first describe the life and works of Ridewood. Like many comparative anatomists of his time, he did not limit his research interests to a particular group of organisms, but rather pursued taxa as disparate as lamellibranchiate molluscs and whales. We will then discuss his impact on the preparation of anatomical specimens, particularly in regard to the skull of teleostean fishes. We will conclude by discussing the impact that Ridewood's work had on the study of the osteology of fishes. A partially annotated bibliography of Ridewood's publications is provided as Appendix 1 .

The source of much of the biographical information herein is taken from the obituaries that appeared in the Proceedings of the Linnean Society of London (A. S. Woodward 1922), the Proceedings of the Malacological Society of London (B. B. Woodward 1922) and Nature (Anonymous 1921) as well as archive material housed in The Natural History Museum, London (cited by their Archive Reference number).

\section{The life and works of Walter George Ridewood}

Walter George Ridewood was born on 1 February 1867 in London, England and his primary education was taken at Enfield Grammar School (his father was headmaster), in what is now the Borough of Enfield in North London. Ridewood's formal morphological training began while a student of G. B. Howes at the Royal College of Science between 1883 and 1887, and it was from there that he published his first scientific papers, which concerned the anatomy of frogs (Ridewood 1888; Howes and Ridewood 1888). In 1888, Ridewood completed his Bachelor's degree at the University of London, and secured a temporary position at the British Museum of Natural History (BMNH), now The Natural History Museum. From 1888 until 1917 he worked at the BMNH acquiring specimens, overseeing preparation of specimens and displays, and writing a lot of the text for the Index Museum.

The Index Museum within The Natural History Museum was a curious construct, occupying six recesses on each side of the Central Hall. In them, representatives of the major divisions of the animal, plant and mineral kingdoms were displayed, together with labels, illustrating their principal characters - a prescient "tree of life exhibit". It was meant as an introduction to the deeper recesses of the Museum with their specialist galleries. The concept of an Index Museum was that of Sir Richard Owen (the first Director of The Museum) who had absolute control over its content. Such control was inherited by successive Directors but met with varying degrees of resistance from the Keepers (Heads) of the different scientific departments. Resistance to Owen's concept was based in both practical objections (e.g. the space was not well lighted) to philosophical concerns. For instance, Günther considered the concept of an Index Museum to be outdated and better left in a time when "heterogeneous objects had to be exhibited in the same room, and when, consequently, the types most deserving of attention were threatened to be lost among a multitude of objects unfit for exhibition" (Stearn 1981, p 58).

Museums already were separated into study and exhibit collections, and Günther thought it better to keep all display material associated with individual galleries together 
and to develop guides of that material for the general public. The resistance that Owen faced may also hint at a dichotomy between his creationist perspectives (e.g. the groups being represented by their principle types) and the adoption of evolution. See Stearn (1981, p 56-59) for more on the history and development of the Index Museum.

In addition to his responsibilities with the Index Museum, Ridewood was a lecturer at St Mary's Hospital Medical School (1894-1916) and Reader at the University of London. Ridewood was elected as a Fellow of the Zoological Society of London in 1891, and also held membership in the Linnean Society of London (elected as a Fellow in 1893), the Geological Society of London (1895), and the Malacological Society of London (joined in 1900, a Council member from 1903 to 1905 and 1909 to 1911, and served as a Vice President from 1906 to 1908). Given the temporary nature of Ridewood's employment at the Museum, it is perhaps not surprising that his name is absent in both contemporary and modern accounts of the history of the BMNH (e.g. Günther 1912; Stearn 1981). However, this absence does not reflect the attitude of those around him, particularly given that his "resignation [from the Museum was] greatly regretted by his colleagues" (Anonymous 1921, p 160). For example, in a reply to a letter Ridewood wrote in 1919 from France during the First World War, William T. Calman wrote: "I was particularly glad to have your note giving evidence of your continued existence which one was almost beginning to doubt. You are badly missed by the rest of us" (letter from Calman to Ridewood, DF252/ 15).

Ridewood was noted to be a "singularly quiet and retiring" man (Anonymous 1921, p 160) whose hobby was playing the flute. Described as being "gifted with a spirit of genuine kindliness" (B. B. Woodward 1922, p 69), he served in the First World War in the British Command Rear Support of the British Expeditionary Force as an ambulance driver in France. At the age of 54, Ridewood died on 21 September 1921. His unexpected death ended a "useful and brilliant career [that] seemed far from nearing its close" (B. B. Woodward 1922, p 69).

In 1897, Ridewood completed his doctoral thesis on the hyobranchial skeleton of Xenopus and Pipa (Ridewood 1897a) at the University of London. This study spawned several additional publications concerning the structure of the hyobranchial morphology of anurans (Ridewood 1897b, 1898a, 1898b, 1899a), as well as other aspects of anuran anatomy and development (Ridewood 1897c, 1898c, 1900). While the focus of much of his early research was anuran morphology and development, Ridewood also was well-versed in the anatomy of "lower" vertebrates generally, publishing on lungfishes (1894), elasmobranch fishes (1896a, 1897d, 1899b, 1899c, 1899d) and teleostean fishes (1891a, $1891 \mathrm{~b}, 1899 \mathrm{e})$. Ridewood returned to work on elasmobranchs in the later part of his career, publishing a monograph on calcification patterns in the vertebral column of elasmobranchs in 1921; this was the last publication to appear during his lifetime (Ridewood 1921a).

Ridewood's scientific expertise was not limited to the anatomy of frogs and fishes. $\mathrm{He}$ published several papers on mammalian morphology (e.g. Ridewood 1901a, 1901b, 1904d; also Lankester 1910), including a posthumously published monograph on the skull of whales (Ridewood 1922). Ridewood also published extensively on Pterobranchia, especially on the genus Cephalodiscus (e.g. Ridewood 1906, 1907a, 1907b, 1912, 1918a, 1918b, 1920, 1921b; Harmer and Ridewood 1913), as well as a monograph on the fine structure of the gills of lamellibranchs (Ridewood 1903a) which remains a benchmark for study in this field. In fact, Ridewood often noted (e.g. Ridewood 1921a, 1922) that his studies of other taxa were delayed because of "the superior attraction of Cephalodiscus as a subject of research" (Ridewood 1921a, p 312). 
Rigorous scholarship was extremely important to Ridewood, who enjoyed a "thorough grasp of the principles of morphology and a close acquaintance with its literature" (Anonymous 1921, p 160). This is best illustrated in his uncharacteristically tetchy reply (Ridewood 1897d) to two short articles (White 1896; Foote 1897), whose authors claimed that the dorsal extrabranchial cartilages in elasmobranch fishes had never been discussed. White, for instance, concluded that:

The upper extra-branchials in Scyllium would call for no comment were it not that they appear hitherto to have escaped notice in an animal which has received much attention from morphologists and students. It is difficult to understand how they should have been overlooked. (White 1896, p 158)

Although fair in his criticism and arguments, Ridewood articulated clearly the 80-year history of this discovery, and concluded that:

such utter disregard, as is evidenced by these authors, White and Foote, of the classical memoirs of Rathke, Johannes Müller, Gegenbaur and W. K. Parker, and their implicit reliance on small textbooks are greatly to be deprecated. (Ridewood 1897d, p 501)

Ridewood himself was accused of ignoring literature, at least indirectly. In a 1909 letter to S. F. Harmer, then the Director of the Museum, R. W. Tower called attention to the overlooking of his study of sound production in drum fishes (Sciaenidae) in Ridewood's (1908) Guide to the Gallery of Fishes. Ridewood suggested that sound is produced in these fishes by the grinding of pharyngeal teeth or the beating of the tail against the bottom of a vessel, following Günther's (1880) An Introduction to the Study of Fishes. However, in a letter to the Director, Ridewood acknowledged the perception of Tower's observations on the "drumming muscle" of these fishes, but pointed out that: "Tower's paper was published on April 23rd 1908, and the Guide-book was published on April 18th 1908, which is adequate explanation for the results of his experiments not having been incorporated". $\mathrm{He}$ further noted that he had already made a notation in his working copy of the Guide, and was "pleased to have had [his] attention called to the paper [Tower 1908], which seems to be an important contribution to the literature of the subject (letter from Ridewood to Harmer, DF200/58).

Like many comparative morphologists of his time, Ridewood was concerned not only with structure of organisms, but also of how structure might indicate phylogenetic relationships among organisms. As he wrote in an essay entitled "Morphology at the National Museum":

The ultimate aim of the zoologist and botanist, however, is, or should be, not the description of so many new species in a lifetime, but the grouping of animals and plants according to their natural affinities, and for this purpose a wider knowledge of morphology is necessary. (Ridewood 1895a, p 260)

Ridewood clearly understood the distinction between shared primitive (=symplesiomorphies) and shared derived characters (=synapomorphies), and that symplesiomorphies were incapable of defining taxonomic groups. For instance, in discussion of relationships among the groups of osteoglossomorph fishes, Ridewood (1904b, p 213) wrote: 
While the Mormyridæ are highly specialized in certain respects, it must be admitted that they retain some primitive features [i.e. plesiomorphies] ... [that] do not point to any closer resemblance between the Mormyridæ and the Albulidæ than with any other primitive family.

The presence of parasphenoidal teeth in most Mormyroids, in which respect the family agrees with the Albulidæ, may be regarded as another primitive feature retained by both families from the ancestral Teleosteans, a feature which might well be retained by two even strongly diverging families.

Ridewood also saw the deficiency of autapomorphies for the purposes of recovering phylogenetic history. He wrote:

Of the other characters mentioned ... as distinctive of the Mormyroid skull, these are all characters of specializations [=autapomorphies], and throw no light on the question of affinity with the Albulidæ. (Ridewood 1904b, p 214)

He also wrote of extant families as the "terminals of a radiating system" (Ridewood 1904b, p 213) and declined to identify a particular taxon from which these "terminals" radiated. In essence, this is the aim of cladistic analysis - to identify a pattern of relationships arranged in a hierarchical framework rather than as a linear progression of types.

Ridewood also saw the necessity of classifications to reflect phylogenetic history:

What is well to aim at, however, is the formation of classificatory tables, admittedly artificial and based each on a single character, so that the taxonomist of the future may, by a process of correlation of these and a careful weighing of the respective values of the facts therein laid before him in a compact and readily assimilable form, arrive at the truth concerning the phylogenetic history of the Lamellibranchia [or any group] ... I am nevertheless in complete accord with him [Dall 1895, p 505] in his conclusion "that systems based on a single character, whether gills, siphons, muscles or what not, are bound to prove unsatisfactory as our knowledge of intermediate types advances; and that almost any group may have among its members some which retain archaicisms [sic] longer than the rest. In such cases the persistency of these characteristics should not oblige us to ignore relationships indicated by other features of the animal. Any permanent classification must necessarily be ecletic [sic, correct in Dall 1895], considering all characters and distinguishing sufficiently between genetic and adaptive features." (Ridewood 1903a, p 185)

Ridewood dealt with ontogeny in much of his study of the vertebrate skeleton, and discussed the importance of this in determining homologies of structure, but he also understood that not all questions of putative homology could be studied through ontogeny. For instance, he was able to show that the first vertebra of Pipa, generally held to be a "fusion" of the first and second vertebrae of other anurans, developed from a single ossification:

Because in ontogeny we cannot distinguish the two phylogenetic entities, we are not in consequence to be debarred from considering that in this first segment of the spine are represented two undifferentiated vertebrae. It is only by loose figure of speech that we speak of the constituents as fused, coalesced or united. The word "connate" suggested 
by Owen [1866, p 96] commends itself for use in such cases. (Ridewood 1897c, p 361362)

Instead, Ridewood used the principles of topology and connectivity (see Rieppel and Kearney 2002) for establishing the putative homology, e.g. his observation that the first spinal nerve passes through a foramen within this vertebra in Pipa, whereas it passes between the first and second vertebrae in other anurans. Further, in his discussion of the sacrum of Pipa (and anurans generally), and in particular regard to the apparent variation of position of the pelvic girdle along the axial skeleton, he remarked that this is

in a sense a "traveling" or "migration" of the pelvis from the tenth to the ninth vertebra, but in using the expressions there is a danger of it being understood to mean an actual movement of parts which has occurred during ontogeny (e.g. Parker [1896, p 715-716] and Gadow [1896, p 18]). The term "homoeosis," coined by Bateson [1894, p 111] to express such variation of relations is therefore a welcome addition to our morphological vocabulary. (Ridewood 1897c, p 367)

Ridewood also alluded to several other modern-sounding conceptions of homology and tests of homology. For instance, in his paper detailing the skull of elopid and albulid fishes he wrote:

The simultaneous presence [in Elops] of a spicular bone [= suprapharyngobranchial of Nelson 1969] and an unmistakable first pharyngobranchial [=infraphranyngobranchial 1 of Nelson 1969] effectively disposes of the argument that the spicular bone represents a modified first pharyngobranchial. (Ridewood 1904a, p 79)

In essence, this is Patterson's (1982) test of conjunction for homology statements.

Ridewood recognized that homologous structures do not need to have similar ontogenetic pathways (see Rieppel and Kearney 2002 for a recent review). Also in his descriptions of the skull of elopids and albulids, he remarked, in discussion of "ectosteal" (=dermal) and "endosteal" (=chondral) bones, that:

Even if [a] bone is a pure cartilage-bone, the argument [i.e. it being homologous with a dermal bone of other taxa] is not the less sound. The ossification in the cartilage owed its origin phylogenetically to a predisposing dermal ossification which now no longer appears in ontogeny. (Ridewood 1904a, p 57)

In other words, dermal and chondral bones, although possessing different ontogenies and having different histogenesis, may be homologous structures (see Patterson 1977).

While not the strict focus of his studies, Ridewood also found value in palaeontology in his study of comparative anatomy. In many instances, he mentions examination of fossils and informative conversations with A. S. Woodward, then the Keeper of Palaeontology at the BMNH. His approach is best summarized in his statement (Ridewood 1895a, p 261): "the study of morphology involves palaeontology as much as zoology". However, current with the practice of his time, it is clear that Ridewood followed the idea that polarity of characters (i.e. plesiomorphic or apomorphic) could be established on "palaeontological grounds" (e.g. Ridewood 1904a, p 57). 


\section{Specimen preparation}

The examination of a prepared dissection is in educational value second only to the dissection of the parts by the student himself. (Ridewood 1895a, p 260)

Ridewood was, by all accounts, particularly skilled in the preparation of anatomical displays and contributed extensively to the British Museum publication Natural Science, with articles pertaining to the preparation, display and interpretation of exhibits (Ridewood 1895a, 1895b, 1896b, 1897e, 1908, 1909a, 1913a, 1916). Calman wrote in a letter to Ridewood while he was serving in the First World War: "I am at present arranging a little exhibit of marine boring animals which I am afraid will give you much to criticize when you see it. It would have been much better if I had been able to consult you" (letter from Calman to Ridewood, DF252/15). This skill and attentiveness for specimen preparation and display carried over into his scientific pursuits. For instance, in the introduction to his paper describing the skull of elopid and albulid teleostean fishes, he lamented:

It is obvious that the skulls of Teleostean fishes, prepared as one now finds them in museums without the disarticulation of any of the parts, are unsatisfactory, by reason of the impossibility of studying minutely any but the most superficial bones. On the other hand, the maceration of the skulls until all the bones fall apart is equally open to objection, since, if all the bones are stored loosely in a box, a great deal of time is wasted in sorting out the parts for study: while if the bones are wired at a little distance from one another in the manner introduced by Owen, the mounted skull is unnecessarily bulky, and there is always the possibility of error in the process of rearticulation; and the expense is so great as to prevent the general adoption of the method. (Ridewood 1904a, p 36)

Ridewood went on to describe a very specific method for the disarticulation of the skull of fishes during the preparation of skeletons intended for scientific study, a method that benefits the researcher because "all the bones of the right side in their undisturbed relations, and at the same time presents a freely exposed left view of the cranium" (Figure 1).

Ridewood's short introductory note had a great influence on the preparation of skulls of fishes, and can be seen to have revolutionized the manner in which cranial anatomy of fishes is studied. This method of preparation has since become standard practice in many ichthyological collections around the world and has been dubbed the "Ridewood method" of skeletal preparation (e.g. Bemis et al. 2004). For example, many of the specimens collected and prepared under the direction of Gareth Nelson for the outstanding collection of dry skeletons of fishes at the American Museum of Natural History (New York) are prepared in a manner based on Ridewood's method. The method of preparation, illustration and description of Amia calva presented by Grande and Bemis (1998) can be seen as a direct modification of how Ridewood envisioned the "proper" study of the skull.

\section{Ridewood's study of the skull of lower teleostean fishes}

In the early 1900s, Ridewood published a series of five papers (Ridewood 1904a, 1904b, 1904c, 1905a, 1905b) that are regarded as standard references to the study of the skull of teleostean fishes ("pioneering work" in the words of Nelson 1968, p 261). These studies 


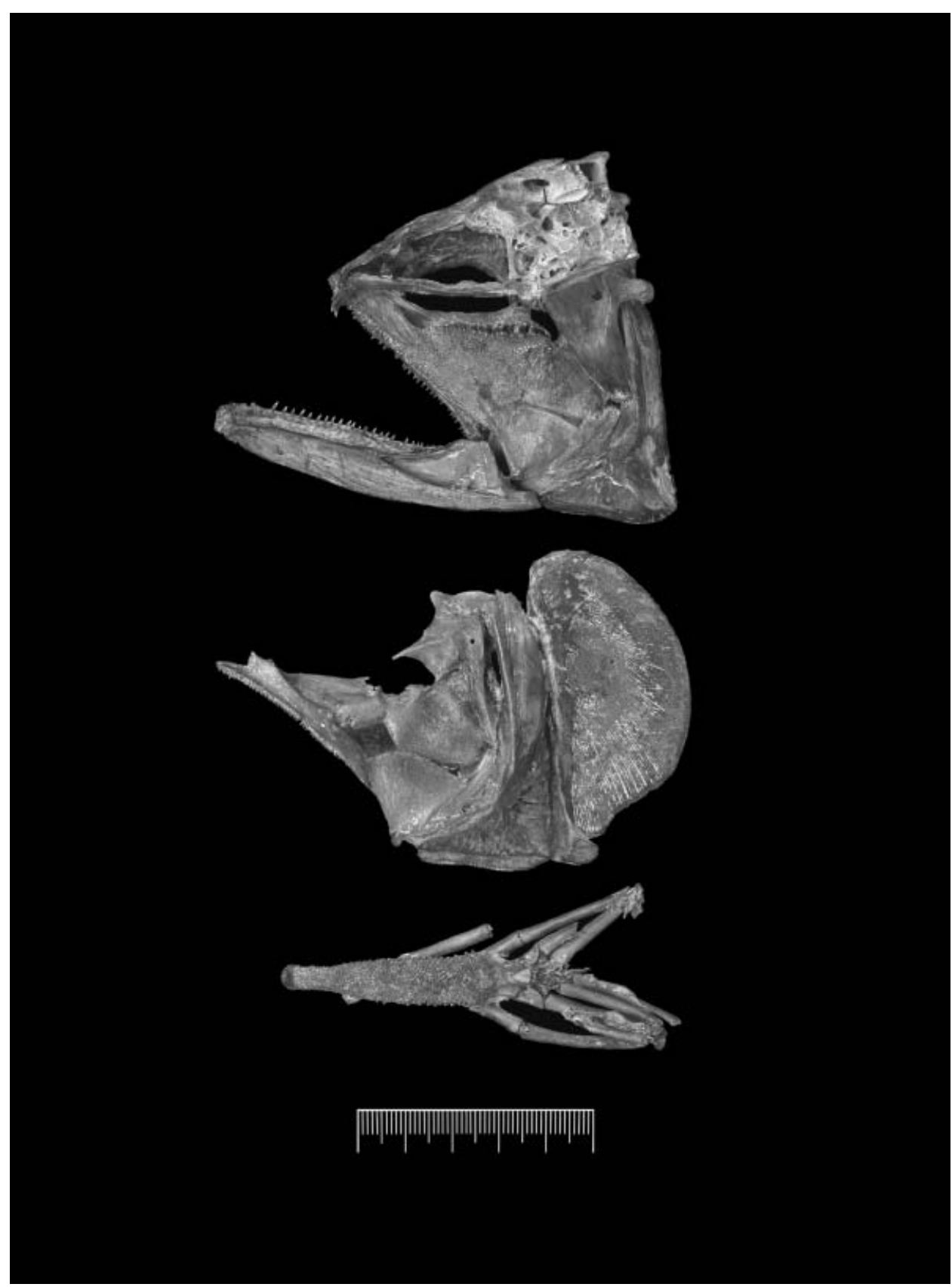

Figure 1. Photograph to show how Ridewood disarticulated a fish skull in order to preserve the maximum amount of original articulation as well as to reveal the greater part of the internal skeleton. This is a skull of Scleropages leichardti (Günther 1864). Top: braincase and the right palate, hyomandibular, preopercle and lower jaw shown in medial view. Middle: left palate, hyomandibular and opercular bones in lateral view. Bottom: the ventral gill arches seen in dorsal view. This specimen (The Natural History Museum registration number BMNH 1905.3.20.6) was prepared and used by Ridewood (1905a) in his description of osteoglossid fishes. 
were intended to serve as the basis of a book on the osteology of fishes, a project that was never completed (A. S. Woodward 1922), due in part to the continual interruption of "pressure of other occupation" (Ridewood 1904a, p 35). Ridewood stated the intended purpose of these papers in the opening words of the first of the series:

An investigation on the structure of the skull of the lower Teleostean fishes was begun by me some years ago [in 1896, at the encouragement of G. B. Howes; also Ridewood $1904 \mathrm{c}, \mathrm{p}$ 448] for the purpose of determining what might and what might not be regarded as primitive features in the Teleostean skull, and with the object of also ascertaining the degrees of relationship existing between the various genera investigated, so far at least as the cranial characters might bear upon the subject. (Ridewood 1904a, p 35)

Ridewood was careful to stress that his studies were just of the skull, and that evidence of phylogenetic relationships must also be sought from other portions of anatomy.

Of these five papers, only the second part of his elopid and albulid paper (Ridewood 1904a) was truly comparative. In this discussion, he compared the skulls of fishes from 13 families, including Elopidae, Megalopidae, Albulidae, Mormyridae, Gymnarchidae, Notopteridae, Hiodontidae, Osteoglossidae, Chanidae, Phractolaemidae, Chirocentridae, Clupeidae, and Engraulidae. These comparisons were made from newly prepared specimens and direct examination, rather than reliance on published descriptions or illustrations (although, of course, his discussion was well-referenced). From these observations, he offered "some remarks, more or less disjointed, upon the morphology of the Teleostean skull ... The discussion of the affinities of the genera under consideration [was] best deferred for the [time being]" (Ridewood 1904a, p 35).

Unfortunately, it seems his "discussion of affinities" was deferred indefinitely, as no explicit ideas of phylogenetic relationships among more than a few genera or families (i.e. no hypotheses of higher-level phylogeny) were ever published by Ridewood himself. The closest he came, perhaps, was in his discussion of elopids (including Megalops) and albulids:

In reviewing the characters which are common to the skull of the Elopidae and the Albulidae, it is perhaps natural that we should be restricted in the main to primitive features. There is no doubt that the Elopidae are the most archaic of existing Teleosteans, and that the Albulidae are in few respects more highly specialized; but the study of the skull does not show any direct affinity between the two families ... there is no evidence (from the study of the skull) that the divergence of the two families from a single one occurred at any considerable height above the root of the phylogenetic tree. (Ridewood 1904a, p 53-54)

From this statement, we can assume that Ridewood was: (1) not convinced of a close relationship of albulids and elopids and (2) considered elopomorphs (represented by Elopidae) to be, in modern terms, the sister-group of all other extant teleosts. While both of these hypotheses have also found modern supporters (e.g. in part Arratia 1997), the debate surrounding the interrelationships of basal teleosts is far from resolved (e.g. see the exchange between Patterson (1998) and Arratia (1998), and the review of the problem in Hilton (2003).

That Ridewood never published his views on the relationships of the fishes he studied does not lessen the value of his papers in the slightest bit, as the importance of his work lay 
not in his conceptualizations of phylogeny (although his overall approach to phylogeny was surprisingly modern), but rather in his careful morphological observations, descriptions and illustrations. Such contributions lay at the foundation of systematic hypotheses, which are in a state of continual re-evaluation as new data are collected and new observations are made.

\section{Acknowledgements}

Prof. Brian G. Gardiner (Kings College, London University) called our attention to Ridewood's obituary published by the Linnean Society of London. Prof. William E. Bemis (University of Massachusetts, Amherst) read an early draft of this manuscript. We thank Susan Snell and Polly Smith, Archivists at The Natural History Museum, for their help in locating documents relating to Ridewood's career. We thank Phil Crabb (Photostudio, NHM) for the production of Figure 1 and Kathie Way (Department of Zoology, NHM) and Paul Taylor (Department of Palaeontology, NHM) for some biographical details. Financial support for E.J.H. by the National Science Foundation (DEB-0128929) is gratefully acknowledged.

\section{References}

Anonymous (W.N.P.). 1905. Prof. G. B. Howes, F.R.S. [obituary]. Nature 71:419-420.

Anonymous (C.W.A.). 1921. Dr. Walter George Ridewood [obituary]. Nature 108:160.

Arratia G. 1997. Basal teleosts and teleostean phylogeny. Paleoichthyologica 7:1-168.

Arratia G. 1998. Basal teleosts and teleostean phylogeny; Response to C. Patterson. Copeia 1998:1109-1113.

Bateson W. 1894. Materials for the study of variation, treated with especial regard to discontinuity in the origin of species. London: Macmillan and Co. 598 p.

Bemis WE, Hilton EJ, Brown B, Arrindell R, Richmond AM, Little C, Grande L, Forey PL, Nelson GJ. 2004. Methods for preparing dry, partially articulated skeletons of osteichthyans, with notes on making Ridewood dissections. Copeia 2004:603-609.

Cadbury D. 2001. The dinosaur hunters. London: Fourth Estate. 384 p.

Dall WH. 1895. Contributions to the Tertiary fauna of Florida, with especial reference to the Miocene Silex-Beds of Tampa and the Pliocene beds of the Caloosahatchie River. Part III. A new classification of the Pelecypoda. Transactions of the Wagner Free Institute of Science of Philadelphia 3:485-570.

Foote E. 1897. The extrabranchial cartilages of the elasmobranch fishes. Anatomischer Anzeiger 13:305-308.

Forey PL. 1973. A revision of the elopiform fishes, fossil and recent. Bulletin of the British Museum (Natural History) Geology Supplement 10:1-222.

Forey PL, Littlewood DTJ, Ritchie P, Meyer A. 1996. Interrelationships of elopomorph fishes. In: Stiassny MLJ, , Parenti LR, Johnson GD, editors. Interrelationships of fishes. San Diego: Academic Press. p 175-191.

Gadow H. 1896. On the evolution of the vertebral column of Amphibia and Amniota. Philosophical Transactions of the Royal Society of London, Series B 187:1-57.

Gardiner BG. 2003. The Piltdown forgery - a re-statement of the case against Hinton. Zoological Journal of the Linnean Society 139:315-335.

Grande L, Bemis WE. 1998. A comprehensive phylogenetic study of amiid fishes (Amiidae) based on comparative skeletal anatomy. An empirical search for interconnected patterns of natural history. Memoir of the Society of Vertebrate Paleontology 4:1-690.

Greenwood PH. 1970. Skull and swimbladder connections in fishes of the family Megalopidae. Bulletin of the British Museum (Natural History), Zoology 19:121-135.

Günther ACLG. 1880. An introduction to the study of fishes. Edinburgh: Adam and Charles Black. 720 p.

Günther ACLG. 1912. The history of the collections contained in the Natural History Departments of the British Museum. Volume III-Appendix. General history of the Department of Zoology from 1856-1895. London: Trustees of the British Museum. 109 p. 
Hilton EJ. 2001. Tongue-bite apparatus of osteoglossomorph fishes: variation of a character complex. Copeia 2001:372-382.

Hilton EJ. 2002. Osteology of the extant North American fishes of the genus Hiodon Lesueur 1818 (Teleostei: Osteoglossomorpha: Hiodontiformes). Fieldiana (Zoology), New Series 100:1-142.

Hilton EJ. 2003. Comparative osteology and phylogenetic systematics of fossil and living bony-tongue fishes (Actinopterygii, Teleostei, Osteoglossomorpha). Zoological Journal of the Linnean Society 137:1-100.

Jungersen HFE. 1891. Remarks on the structure of the hand in Pipa and Xenopus. Annals and Magazine of Natural History, Series 6 8:193-206.

Nelson GJ. 1968. Gill arches of teleostean fishes of the division Osteoglossomorpha. Journal of the Linnean Society (Zoology) 47:261-277.

Nelson GJ. 1969. Gill arches and the phylogeny of fishes, with notes on the classification of vertebrates. Bulletin of the American Museum of Natural History 141:475-552.

Norman JR. 1931. A history of fishes. London: Ernest Benn Ltd. 463 p.

Norman JR. 1937. Illustrated guide to the fish gallery. London: Trustees of the British Museum (Natural History). $175 \mathrm{p}$.

Norman JR, Greenwood PH. 1963. A history of fishes. 2nd edn, New York: Hill and Wang. 398 p.

Norman JR, Greenwood PH. 1975. A history of fishes. 3rd edn, New York: John Wiley and Sons. 467 p.

Owen R. 1866. On the anatomy of the vertebrates. Volume 1, Fishes and reptiles, London: Longmans, Green and Co. $650 \mathrm{p}$.

Parker GH. 1896. Variation in the vertebral column of Necturus. Anatomischer Anzeiger 11:711-717.

Patterson C. 1975. The braincase of pholidophorid and leptolepid fishes, with a review of the actinopterygian braincase. Philosophical Transactions of the Royal Society of London 269:275-579.

Patterson C. 1977. Cartilage bones, dermal bones and membrane bones, or the exoskeleton versus the endoskeleton. In: Andrews SM, Miles RS, Walker AD, editors. Problems in vertebrate evolution. London: Academic Press. p 77-116.

Patterson C. 1982. Morphological characters and homology. In: Joysey KA, Friday AE, editors. Problems of phylogenetic reconstruction. London: Academic Press. p 21-74.

Patterson C. 1998. Comments on basal teleosts and teleostean phylogeny, by Gloria Arratia. Copeia 1998:1107-1109.

Ridewood WG. See references provided in Appendix 1.

Rieppel O, Kearney M. 2002. Similarity. Biological Journal of the Linnean Society 75:59-82.

Stearn WT. 1981. The Natural History Museum at South Kensington. A history of the British Museum (Natural History) 1753-1980. London: Heinemann, in association with the British Museum (Natural History). 414 p.

Tower RW. 1908. The production of sound in the drumfishes, the sea-robin and the toadfish. Annals of the New York Academy of Sciences 18:149-180.

White PJ. 1896. Note on the extra-branchial cartilages of Scyllium canicula. Anatomischer Anzeiger 12:158.

Woodward AS. 1922. Walter George Ridewood [obituary]. Proceedings of the Linnean Society, London 1922:70.

Woodward BB. 1922. Dr. Walter George Ridewood, F.L.S., etc. 1867-1921 [obituary]. Proceedings of the Malacological Society of London 15:68-69.

\section{Appendix 1. A partially annotated list of publications by Walter George Ridewood}

Note that no attempt has been made to organize the publications within a given year chronologically.

Ridewood WG. 1888. On an abnormal genital system in a male of the common frog. Anatomischer Anzeiger 3:333-337.

Howes GB, Ridewood WG. 1888. On the carpus and tarsus of the Anura. Proceedings of the Linnean Society, London 1888:141-182. [Ridewood (1900, p 461) later noted that in this paper the "ventral surface of the carpus of Xenopus and Pipa is unfortunately figured as the dorsal surface, and the radial sesamoid is stated as occurring ventrally to the lunatum', an error that was also pointed out by Jungersen 1891.]

Ridewood WG. 1891a. Report on the occupation of the table [at the Laboratory of the Marine Biological Association at Plymouth]. On the air-bladder of clupeoid fishes. Report of the Sixtieth Meeting of the British Association for the Advancement of Science, held at Leeds in September 1890 1890:446. 
Ridewood WG. 1891b. The air-bladder and ear of British clupeoid fishes. Journal of Anatomy and Physiology 26:26-42.

Ridewood WG. 1894. On the hyoid arch of Ceratodus. Proceedings of the Linnean Society, London 1894:632640.

Ridewood WG. 1895a. Morphology at the National Museum. Natural Science 7:258-269.

Ridewood WG. 1895b. The teeth of the horse. Natural Science 6:249-258.

Ridewood WG. 1896a. On the spiracle and associated structures in elasmobranch fishes. Anatomischer Anzeiger 11:425-433.

Ridewood WG. 1896b. The teeth of fishes. Natural Science 8:380-391.

Ridewood WG. 1897a. On the structure and development of the hyobranchial skeleton and larynx in Xenopus and Pipa; with remarks on the affinities of the Aglossa. Journal of the Linnean Society (Zoology) 26:53-128.

Ridewood WG. 1897b. On the structure and development of the hyobranchial skeleton of the parsley-frog (Pelodytes punctatus). Proceedings of the Linnean Society, London 1897:577-595.

Ridewood WG. 1897c. On the development of the vertebral column in Pipa and Xenopus. Anatomischer Anzeiger 13:359-376.

Ridewood WG. 1897d. Note on the extrabranchial cartilages of elasmobranch fishes. Anatomischer Anzeiger 13:499-501.

Ridewood WG. 1897e. On the restoration of some extinct reptiles. Natural Science 11:190-196.

Ridewood WG. 1898a. On the larval hyobranchial skeleton of the anurous batrachians with special reference to the axial parts. Journal of the Linnean Society (Zoology) 26:474-487.

Ridewood WG. 1898b. On the development of the hyobranchial skeleton of the midwife-toad (Alytes obstetricans). Proceedings of the Linnean Society, London 1898:4-12.

Ridewood WG. 1898c. On the skeleton of regenerated limbs of the midwife-toad (Alytes obstetricans). Proceedings of the Linnean Society, London 1898:101-106.

Ridewood WG. 1899a. On the hyobranchial skeleton and larynx of the new aglossal toad, Hymenochirus Boettgeri. Journal of the Linnean Society (Zoology) 27:454-460.

Ridewood WG. 1899b. Note on the basibranchial skeleton of Echinorhinus spinosus. Anatomischer Anzeiger 15:346-348.

Ridewood WG. 1899c. Some observations on the caudal diplospondyly of sharks. Journal of the Linnean Society (Zoology) 27:46-59.

Ridewood WG. 1899d. On the eyelid-muscles of the Carchariidae and Scyllium: a contribution to the morphology of the nictitating membrane of sharks. Journal of Anatomy and Physiology 33:228-242.

Ridewood WG. 1899e. On the relations of the efferent branchial blood-vessels to the "circulus cephalicus" in teleostean fishes. Proceedings of the Linnean Society, London 1899:939-956.

Ridewood WG. 1900. Note on the carpus of the new aglossal toad, Hymenochirus Boettgeri. Journal of the Linnean Society (Zoology) 27:460-462.

Ridewood WG. 1901a. On the structure of the horny excrescence, known as the "Bonnet" of the southern right whale (Balcena australis). Proceedings of the Linnean Society, London 1901:44-47.

Ridewood WG. 1901b. On the structure of the hairs of Mylodon listai and other South American Edentata. Quarterly Journal of Microscopical Science (New Series) 44:393-401.

Ridewood WG, Webb WJ [b/w illustrations], Wagner P [coloured illustrations]. [1902] Illustrated natural history of animals. London: Raphael Tuck \& Sons, 66 p. [No publication date appears in this book. The year cited here follows from that which is stamped in the copy in the British Library (London), indicating its year of accession.]

Ridewood WG. 1903a. On the structure of the gills of the Lamellibranchia. Philosophical Transactions of the Royal Society of London series B 195:147-284.

Ridewood WG. 1903b. On Obesiella lyonsielle, a new genus of copepod crustacean. Journal of the Linnean Society (Zoology) 28:463-465.

Ridewood WG. 1904a. On the cranial osteology of the fishes of the families Elopidae and Albulidae, with remarks on the morphology of the skull in lower teleostean fishes generally. Proceedings of the Linnean Society, London 1904:35-81.

Ridewood WG. 1904b. On the cranial osteology of the fishes of the families Mormyridae, Notopteridae, and Hyodontidae. Journal of the Linnean Society (Zoology) 29:188-217.

Ridewood WG. 1904c. On the cranial osteology of the clupeoid fishes. Proceedings of the Linnean Society, London 1904:448-493.

Ridewood WG. 1904d. Some observations on the skull of the giraffe. Proceedings of the Linnean Society, London 1904:150-157. 
Ridewood WG. 1905a. On the cranial osteology of the fishes of the families Osteoglossidae, Pantodontidae, and Phractolaemidae. Journal of the Linnean Society (Zoology) 29:252-282.

Ridewood WG. 1905b. On the skull of Gonorhynchus Greyi. Annals and Magazine of Natural History, Series 7 15:361-372.

Ridewood WG. 1906. A new species of Cephalodiscus (C. gilchristi) from the Cape Seas. Marine Investigations, South Africa 4:173-192.

Ridewood WG. 1907a. Pterobranchia; Cephalodiscus. National Antarctic Expedition [“Discovery”] Natural History 2:1-67.

Ridewood WG. 1907b. On the development of the plumes in buds of Cephalodiscus. Quarterly Journal of Microscopical Science New Series 51:221-252.

Ridewood WG. 1908. Guide to the gallery of fishes in the Department of Zoology of the British Museum (Natural History). London: Trustees of the British Museum (Natural History. 209 p. [Ridewood's guide to the fish gallery was succeeded by Norman (1931) and Norman and Greenwood (1963, 1975); also Norman (1937)].

Ridewood WG. 1909a. Memorials of Charles Darwin. A collection of manuscripts portraits medals books and natural history specimens to commemorate the Centenary of his birth and the fiftieth anniversary of "The Origin of Species". London: Trustees of the British Museum (Natural History). 50 p. [A second edition of this guide was published the following year (1910) due to its popularity. New to the second edition was a table of contents and "a few verbal alterations". A facsimile reprint of this guide also appeared in the Bulletin of the British Museum (Historical Series) (1988, 14:3) with an introduction by S. Smith. No mention of Ridewood's role in this exhibit and production of the guide appeared in this introduction, although it included a short biography of Sidney Harmer, under whose direction Ridewood worked.]

Ridewood WG. 1909b. A case of abnormal oviducts in Homarus vulgaris. Annals and Magazine of Natural History, Series 8 3:1-7.

Lankester ER. 1910. Monograph of the okapi: atlas (of 48 plates); compiled with the assistance of W. G. Ridewood, D.Sc. London. London: Trustees of the British Museum (Natural History). i-viii, 48 plates. [According to the Preface ( $\mathrm{p}$ iii) by S. F. Harmer, these plates were prepared and intended as the figures for a monograph that included a textual description. It was decided that the plates be published separately, to which Lankester agreed, because the " preparation of the 'Monograph of the Okapi' ... has taken longer than was expected". The plates had been finished and printed for two full years before this was decided, and the plates were "arranged for publication by Dr. W. G. Ridewood, who [had] also written appropriate legends". It was noted also that it was "doubtful whether the Atlas [would] be followed by a volume of text", citing other textual descriptions of the okapi that had been published in the intervening years.]

Ridewood WG. 1912. On specimens of Cephalodiscus nigrescens supposed to have been dredged in 1841 or 1842. Annals and Magazine of Natural History, Series 8 10:550-555.

Ridewood WG. 1913a. Guide to the exhibition of specimens illustrating the modification of structure of animals in relation to flight. London: Trustees of the British Museum (Natural History). 80 p.

Ridewood WG. 1913b. Notes on the South American freshwater flying-fish, Gastropelecus and the common flyingfish Exocetus. Annals and Magazine of Natural History, Series 8 12:544-548.

Harmer SF, Ridewood WG. 1913. The Pterobranchia of the Scottish National Antarctic Expedition (1902 to 1904). Transactions of the Royal Society of Edinburgh 49:part 3(7):531-565. [This paper was reprinted by the Scottish Oceanographical Laboratory in 1915 in: Scottish National Antarctic Expedition. Report on the Scientific Results of the Voyage of the S.Y. "Scotia" during the years 1902, 1903 and 1904, under the leadership of W. S. Bruce 4(17).]

Ridewood WG. 1916. Guide to the specimens and enlarged models of insects and ticks exhibited in the Central Hall illustrating their importance in the spread of disease. London: Trustees of the British Museum (Natural History). 44 p. [A second edition of this guide, revised by E. E. Austen, was published in 1919.]

Ridewood WG. 1918a. Cephalodiscus of the "Terra Nova" Expedition, 1910. British Antarctic ("Terra Nova") Expedition 1910, Natural History Report, Zoology 4:11-82.

Ridewood WG. 1918b. The Pterobranchia of the Antarctic regions. Australasian Antarctic Expedition of 1911-14. Scientific Reports. Series C, Zoology and Botany 3:1-25.

Ridewood WG. 1920. A key for the ready identification of the species of Cephalodiscus. Annals and Magazine of Natural History, Series 9 5:407-410.

Ridewood WG. 1921a. On the calcification of the vertebral centra in sharks and rays. Philosophical Transactions of the Royal Society of London Series B 210:311-307. [This was Ridewood's last paper to be published during his lifetime.]

Ridewood WG. 1921b. On specimens of Cephalodiscus densus dredged by the "Challenger" in 1874 at Kerguelen Island. Annals and Magazine of Natural History, Series 9 8:433-440. 
Ridewood WG. 1922. Observations on the skull in fotal specimens of whales of the genera Megaptera and Balcenoptera. Philosophical Transactions of the Royal Society of London Series B 211:209-272. [Ridewood noted in the introduction of this paper ( $p$ 209) that this "investigation was begun in July, 1912, at the British Museum (Natural History), but was discontinued, partly in consequence of the pressure of other work, and partly owing to the superior attraction of Cephalodiscus as a subject of research; it was resumed in November, 1920, in the Huxley Research Laboratory at the Royal College of Science".]

\section{Appendix 2. Biographical notes on persons mentioned in text, alphabetically arranged}

Boulenger. Georges Albert Boulenger (1858-1937). Appointed in 1883 by Günther to study the collections and produce catalogues of specimens of reptile and amphibians at the British Museum (Natural History). After retirement, Boulenger pursued his lifelong interest in roses, publishing the two volume Les roses d'Europe.

Calman. William Thomas Calman (1871-1962). Keeper of Zoology (1927-1936), specialist in Crustacea with interests in functional morphology.

Günther. Albert Carl Ludwig Gotthilf Günther (1830-1914). Keeper of Zoology (18751895), author of Catalogue of Fishes of the British Museum as well as Catalogue of the Colubrine Snakes.

Harmer. Sir Sidney Frederic Harmer (1862-1950). Keeper of Zoology (1909-1921), Director of the Museum (1919-1927), and specialist in whales; he initiated the ongoing tracking of records of stranded cetaceans around the British coast as well as keeping southern hemisphere whaling records. He also produced many papers on bryozoan anatomy and systematics as well as whales, a taxonomic juxtaposition that must be unique.

Howes. George Bond Howes (1853-1905). A comparative anatomist particularly interested in vertebrate animals. A student of and successor to Thomas Henry Huxley at the Royal College of Science, noted for his attention to his science, his inspired teaching, and his tireless efforts on behalf of scientific societies (Anonymous 1905).

Nelson. Gareth J. Nelson (born 1937). An ichthyologist who worked at the American Museum of Natural History. He was instrumental in bringing and developing the theoretical ideas of Phylogenetic Systematics, formulated by Willi Hennnig, to the Englishspeaking world and thereby revolutionized methods of recognizing patterns of relationship.

Owen. Sir Richard Owen (1804-1892). Superintendent (Director) of the Museum (18561884), the leading comparative anatomist of his generation with a deep understanding of the theory of morphology. An irascible character who crossed swords with many (Cadbury 2001).

Patterson. Colin Patterson (1933-1998). Palaeoichthyologist with outstanding contributions to both the comparative anatomy of fishes as well as the theory and practice of classification. 
Regan. Charles Tate Regan (1878-1943). Keeper of Zoology (1921-1927); Director of The Museum (1927-1938) and who made outstanding contributions to the classification of fishes in the early part of the 20 th century.

Tower. Ralph Winfred Tower (1870-1926). A curator at the American Museum of Natural History, New York, in charge of the Library; also appointed to the Department of Anatomy and Physiology.

Woodward. Arthur Smith Woodward (1864-1944). Keeper of Palaeontology (1901-1924), palaeoichthyologist famous for his Catalogue of Fossil Fishes of the British Museum, among many other works on the comparative anatomy of fishes. Also believed to be the target of the Piltdown Hoax (e.g. Gardiner 2003). 